\title{
Bird species that occupy river edge in continuous forest tend to be less sensitive to forest fragmentation
}

\author{
Barbara Rocha Arakaki Lindsey ${ }^{1,3}$, Gabriela Menezes Bochio ${ }^{1} \&$ Luiz dos Anjos $^{2}$ \\ 1 Programa de Pós-Graduação em Ciências Biológicas, Universidade Estadual de Londrina, Londrina, PR, Brazil. \\ Departamento de Biologia Animal e Vegetal, Laboratório de Ornitologia e Bioacústica, Universidade Estadual de Londrina, Londrina, PR, Brazil. \\ 3 Corresponding author: barbara.r.a.lindsey@gmail.com
}

Received on 02 October 2018. Accepted on 21 August 2019.

\begin{abstract}
Along a distance gradient from a given river, two types of habitat can be recognized: natural river edge and forest interior, each one with its own vegetation characteristics and dynamics. In a continuous area of the Brazilian Atlantic Forest, we investigated (1) if bird communities are different between a riverbank of a small stream and an inland forest habitat; (2) if the species of the river edge habitat are the ones that persist in the most in forest fragments after deforestation of a continuous forest; (3) if the river edge habitat species are those that are less sensitive to forest fragmentation. It is expected that there are differences in the bird communities and the occupancy of some species between the two habitats. We allocated 16 sampling points in each of the habitats and sampled the birds by point counts with a short radius of $30 \mathrm{~m}$. Results suggest that there is a significant difference between the composition of the bird communities of the river edge and forest interior habitats, although the species richness is similar. Six species were more likely to occupy the river edge and 14 species had a greater probability of occupancy in the forest interior. Species associated with the river edge habitat ( 15 species) tend not to be sensitive to forest fragmentation (12 species). In this study, we demonstrated that river-border species of continuous forest areas form a significant part of the bird communities that persist in small forest fragments, with intense edge effect. This shows that not all forest edge species are the result of the colonization from open areas. Congruently, species that occupy the most distant areas from the river vegetation in a continuous forest are those more sensitive to forest fragmentation.
\end{abstract}

KEY-WORDS: Atlantic Rainforest, bird sensitivity, forest interior, natural edge, probability of occupancy.

\section{INTRODUCTION}

The Brazilian Atlantic Forest Biome, a tropical forest strip that stretches along $3300 \mathrm{~km}$ of the Brazilian coast beside inland areas in Argentina and Paraguay, has thousands of endemic species (more than 650 species of vertebrates and 8000 species of plants) and is considered one of the key biodiversity hotspots in the world (Tabarelli et al. 2010, Mittermeier et al. 2011). The seasonal-semideciduous forest (SF), a type of forest in the Atlantic Forest Biome, extends through the center-south of the country interior, between 200 and $800 \mathrm{~m}$ of altitude and could be considered an ecoregion; there, approximately 220 tree species occur, $10 \%$ of which are endemic to this forest type (Morellato \& Haddad 2000, Oliveira-Filho \& Fontes 2000, Scheer \& Blum 2011, Anjos et al. 2018). Locally in SF, many rivers, large and small, and streams flow from upland areas to the lowland areas, as is common along the Atlantic Forest. A distinct riparian environment with a unique vegetative formation characterizes those lowland river edges, which is the focus of the present study. This lowland river edges forests usually has a much less dense canopy with few emerging trees while the under and midstory have a higher density of smaller tree species; also, it is common to have the fall of trees and consequently the creation of clearings that allow the occupation of bamboo species (Bianchini et al. 2001, Anjos et al. 2007).

This lowland riparian environment constitutes a transition between the river and the associated upland forest, marking a natural border or ecotone boundary. A forest ecotone is a consequence of the meeting of distinct natural plant communities, which, in turn, influences the diversity of wild animals across the landscape, dependent on distance from a rivers' edge and the characteristic transition in topography, plant community, hydrological regimes, and soil types (Naiman et al. 1993, Shirley 2005). Considering several taxonomic groups, some studies suggest greater species richness in riparian environments compared to distinct forest (Naiman et al. 1993), others found greater richness in non-riparian environments (McGaragal \& McComb 1992, Peres 1997) and some found no difference between these two habitat types (Gomez \& Anthony 1998, Rykken et al. 2007).

On birds, several studies indicated the great importance of the riparian environment (natural river edges) as a uniquely sustaining habitat with relatively more species than associated upland forest areas (Woinarski 
et al. 2000, Kajtoch et al. 2007, Dominguez-López \& Ortega-Álvarez 2014, Rannestad et al. 2015, Berduc et al. 2015, Sekercioglu et al. 2015, Gomez et al. 2016). In a tropical rainforest in Hong Kong, a higher number of individuals and bird species were recorded in the riparian environment, when compared to an area 100 $250 \mathrm{~m}$ distant from the river due to the high availability of adult aquatic insects, which confirms the response of birds to river proximity (Chan et al. 2008). In a 656 ha fragment of the Atlantic Forest in northern Paraná state, with little topographic variation $(-150 \mathrm{~m}$ altitude), Anjos et al. (2007) showed that $43 \%$ of all bird species were associated with riparian forest due to differences in vegetation; they sampled 81 species and found that 19 and 45 species were unique to the non-riparian and riparian habitat, respectively. Another study conducted in the same site showed that the difference between the bird communities is mainly due to the presence of bamboo in the riparian forest (Chusquea sp., Willrich et al. 2016). Therefore, riparian bird species may comprise a significant proportion of the overall local forest bird richness and with particular traits associated to that vegetation closer to rivers.

Riparian forest could be in some extension comparable to edges of forest fragments, since both are ecotones. We argue that edge birds of riparian forest should be more adapted to the edge of forest fragments, while birds inhabiting the interior of the forest avoid those created habitats after deforestation (Gimenes \& Anjos 2003, Hansbauer et al. 2008). In this study, we tested if it is possible that birds that originally live in the riparian environment in the continuous forest could be more tolerant to edges that appear after forest fragmentation. To do this, the first objective of this study was to verify if bird communities are different between a natural river edge habitat and a forest interior. For this, we investigated the richness and composition of the bird communities. The hypothesis is that the richness and composition of the bird communities of the two habitats are different due to the difference of resources found in both habitats, e.g., the availability of adult aquatic insects in the river natural edge habitat and several resources (both animal and vegetal), associated to the river edge vegetation. The second objective of this study was to compare the occupancy of the bird species between the two habitats. In this case, we evaluated the occupancy probability of the bird species according to the different habitat types. The occupancy of some bird species is expected to be different between the two types of habitat, due to differences in vegetation. The third objective of this study was to verify if the river natural edge habitat species are less sensitive to forest fragmentation. In order to do this, we investigated the association between the number of bird species closely related with the river natural edge habitat and their sensitivity to forest fragmentation, which was previously determined for the bird species of SF (see Anjos 2006, Anjos et al. 2011). The hypothesis is that the natural river edge habitat species are the ones that persist in most of forest fragments in relation to the forest interior, after the deforestation of a continuous forest, that is, those species are less sensitive to forest fragmentation. The reason for this hypothesis is that the vegetation of river edges presents low trees and bushy entanglement in the lower stratum, phyto-physiognomy that resembles edges of forest fragments.

\section{METHODS}

\section{Study area}

The study was developed in the Iguaçu National Park (INP), in the municipality of Céu Azul, Paraná (2509'12'S; 5350'42'W, Fig. 1). INP was created in 1939 and its total area is $185,262.2 \mathrm{ha}$; it is a fully protected Conservation Unit whose predominant vegetation is SF (ICMBio 2014). In reality, INP is home to the countrys largest continuous SF area. The INP climate, according to the classification of Köppen, is of type $C f a$ subtropical humid or mesothermic with hot summer, with average temperatures between 15 and $25^{\circ} \mathrm{C}$ and rainfall above $900 \mathrm{~mm}$, also distributed throughout the year (Melo et al. 2006).

$\mathrm{SF}$ is related, in virtually the whole area of occurrence, to a climate of two well defined seasons - one rainy and one dry (Veloso et al. 1991). The vegetation is dense and presents a great variety of vegetal species, constituted by arboreal elements (perennial or deciduous), as well as shrub, lianas and epiphytes. Among tree species that are associated with SF are: Assai Palm (Euterpe edulis Mart.), Peroba (Aspidosperma polyneuron Müll.Arg.), Brazilian Rosewood (Aniba rosaeodora Ducke), Alecrin (Holocalyx balansae Micheli), Angico-cedro (Parapiptadenia rigida (Benth.) Brenan) and Argentine Cedar (Cedrela fissilis Vell., Guimarães et al. 2003).

\section{Sampling areas}

We sampled two habitats and denominated them as "River Edge" and "Forest Interior". The "River Edge" (RE; 2509'43"S; 5349'39"W) is located on the border of a tributary of the Azul River, and the "Forest Interior" (FI; 2509'28'S; 5350'09"W) is located at $300 \mathrm{~m}$ of RE, at higher altitude $(565 \mathrm{~m}$ a.s.l.) and at $470 \mathrm{~m}$ of forest edge (Fig. 2 in Appendix I). The tributary of the Azul River is a small one, with 8 to $15 \mathrm{~m}$ width in the section studied. In each habitat, 16 points were established (Fig. 1). The shortest distance between RE and FI sampling points was $80 \mathrm{~m}$.

In RE, points were allocated in four tracks (REA, 

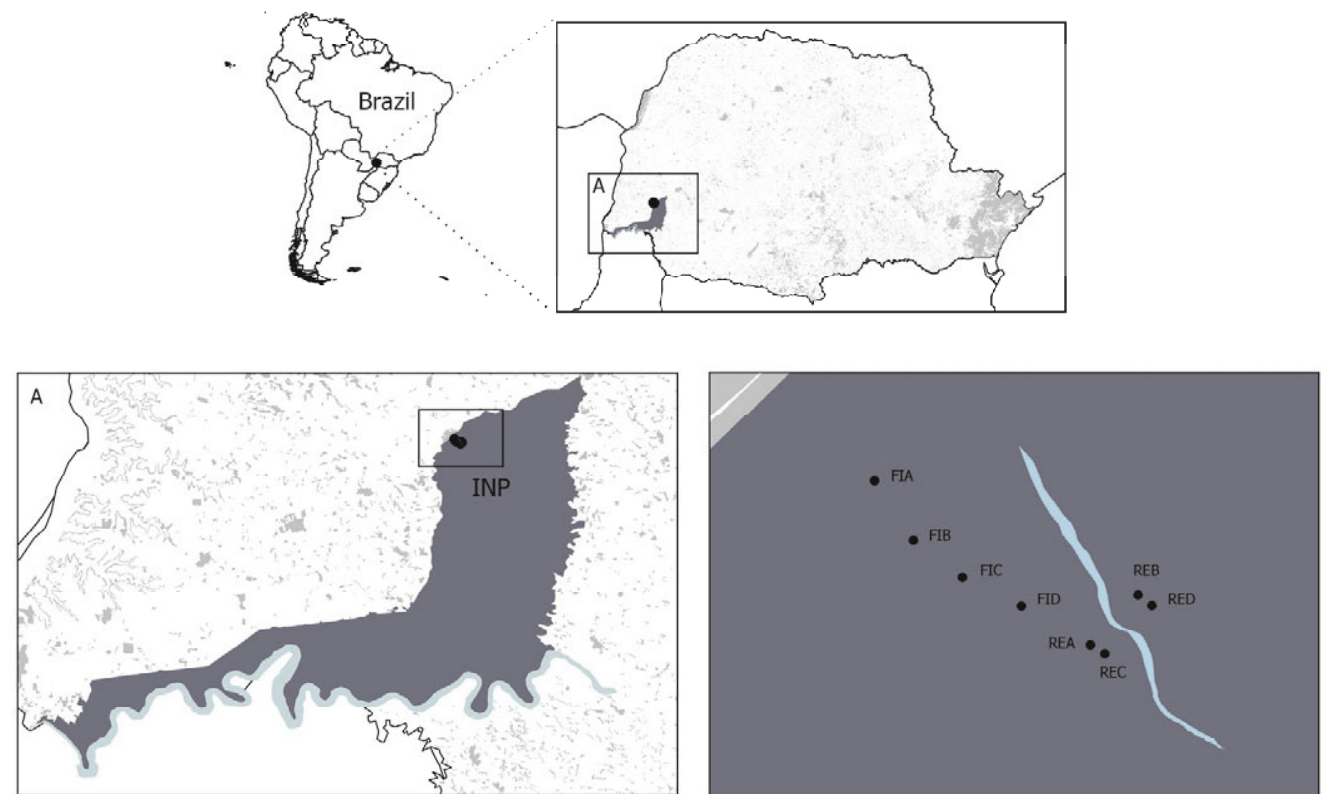

Figure 1. Location of Paraná state in South America and the region of the study in the Iguaçu National Park (INP), western Paraná, southern Brazil. The black dots indicate the location of the sample units (REA, REB, REC and RED in RE and FIA, FIB, FIC and FID in FI).

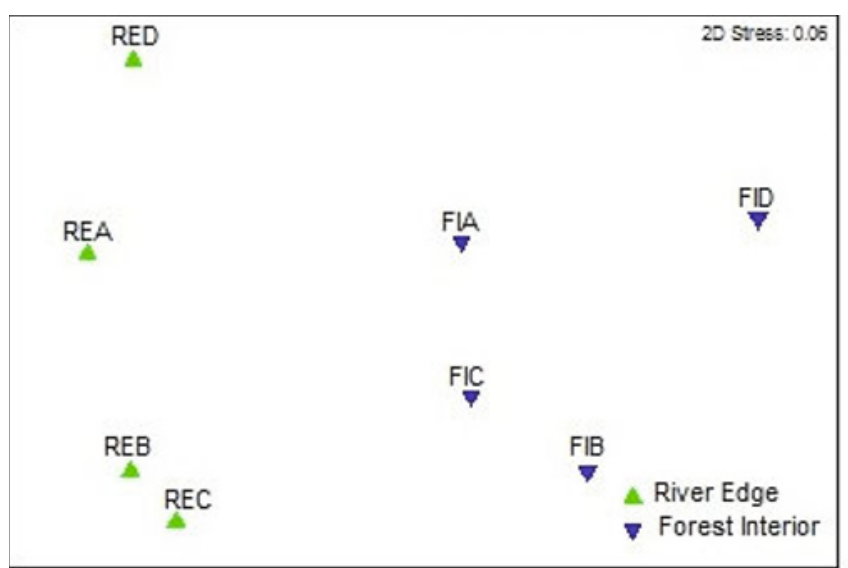

Figure 2. Non-metric multidimensional scaling (NMDS) of bird communities in eight different sample units (REA, REB, REC, RED, FIA, FIB, FIC, and FID) occurring in two habitats ("River Edge" and "Forest Interior") at INP.

REB, REC and RED), perpendicular to the river. The trails in this habitat were at least $300 \mathrm{~m}$ apart (Fig. 2 In Appendix I). In FI, the points were allocated on a trail of $1200 \mathrm{~m}$ located inside the forest. The 16 points located in this track were subdivided into four blocks of four points (blocks FIA, FIB, FIC, FID, Fig. 3 in Appendix I).

In RE habitat we observe lower trees, with a height of 8 to $15 \mathrm{~m}$, having less plant species richness. Also, the species are adapted to periodic flooding which supports high humidity (ICMBio 1999). In the transition from RE habitat to IF habitat, vegetation changes and trees become taller. In the FI habitat there is a greater richness of plant species; there are large trees, with maximum heights of $35 \mathrm{~m}$ in the emerging layer, and it is common to find in the best-preserved parts, trunk with diameters at breast height (DBH) of more than $1 \mathrm{~m}$ (ICMBio 1999).

\section{Bird sampling}

We used the point count method with radius of $30 \mathrm{~m}$ (Bibby et al. 1993) in bird sampling. This method is very effective in studies of avian habitat relationships (Anjos et al. 2010). Sampling was carried out during the breeding season of January and February of 2013, in which birds are more likely to be detected by the observer through their vocalizations.

Each set of four points in both habitats was considered as a sample unit, which was sampled in one day. These sample units were named REA, REB, REC and RED in RE and FIA, FIB, FIC and FID in FI. On each day the points of each sample unit were sampled consecutively 1,2, 3 and 4, and then again reversing the sequence, 4, 3, 2 and 1. For example, on track $A$ in RE, on one day the sampling sequence of the points was REA1, REA2, REA3, REA4, REA4, REA3, REA2, REA1. The following day the sampling sequence of the points was reversed: REA4, REA3, REA2, REA1, REA1, REA2, REA3, REA4. We sampled each sampling unit for two days, and we sampled each sampling point four times (as if they had been sampled on four mornings). Studies performed in the Atlantic Forest using the point count method demonstrated that 3 to 5 days of sampling are sufficient to detect more than $90 \%$ of the species recorded in a sample area (Anjos 2007, Cavarzere et al. 2013). Sampling began shortly after sunrise, when daytime birds start to vocalize, and ended $2.5 \mathrm{~h}$ after sampling at 
the first point, under favorable climatic conditions. We sampled each point for 10 min with a 10 min interval between points. According to Anjos et al. (2010), if the observer is interested in assessing differences between numbers of bird species at different locations, the time of $10 \mathrm{~min}$ is sufficient and in SF, 96\% of the species are recorded during this time interval.

\section{Statistical analysis}

We estimated the total richness of the bird species using the non-parametric $\mathrm{ChaO}_{2}$ species estimator (Herzog et al. 2002). We evaluated the influence of space (spatial autocorrelation) on the composition of bird species through the Mantel test (1000 permutations). The geographic distance matrix was obtained by the Euclidean distance on the geographical coordinates of the sample units. We obtained the similarity matrix of the species composition using the distance of Bray Curtis on the abundance of the species in each sample unit. We performed the analysis in $\mathrm{R}$ software ( $\mathrm{R}$ Development Core Team 2015), using the package "vegan" (Legendre \& Legendre 1998, Oksanen et al. 2016).

We estimated the relative abundance for a single species in a habitat (RE or FI), called the Index of Point Abundance (IPA), by dividing its contact number by the total number of points sampled in each site (Bibby et al. 1993). To avoid double counting for the same individuals' precautions were taken particularly for those highly mobile species by adopting a field form that is divided into different quadrants as suggested by Vielliard \& Silva (1990). Thus, a number of contacts of 30 for a given species resulted in an IPA equal to 0.468 (30 contacts divided by 64 points sampled).

To verify differences in bird species composition between the two habitats we used a permutational analysis of variance (PERMANOVA) (Anderson 2001). This analysis was performed in $\mathrm{R}$ software ( $\mathrm{R}$ Development Core Team 2015), using the packages "vegan" (Oksanen et al. 2016) and "BiodiversityR" (Kindt \& Coe 2005).

We used non-metric multidimensional scaling (NMDS) to visualize the similarity in community composition between the two habitats (Clarke 1993). Data was transformed through weighting dispersion to reduce the contribution of high abundance species in the similarity. Similarities of Bray-Curtis were used to construct the distance matrices between sample units. This analysis was performed using software PRIMER v. 6 (Clarke \& Gorley 2006).

For each bird species recorded in both habitats, we calculated the probability of occupancy in the different habitats using single-season occupancy modeling (MacKenzie et al. 2002). These models involve the estimation of two parameters: the occupancy $(\mathrm{Y})$, which is the probability of the species being present in one place, and the probability of detection (p).

Single season occupancy modeling requires multiple visits to sampling units during a season in which species can be detected. This model assumes that during these visits no individual enters or leaves the population (closed model). At each visit the observer detects the presence (" 1 ") or absence (" 0 ") of the species of interest. The absence may be a real absence of the species or a failure to detect the species. This type of modeling adjusts the variation in probability of detection while estimating the probability of occupancy of bird species. By incorporating the probability of detection into the models, the imperfect detection is considered and the bias in the parameter estimation is reduced (MacKenzie et al. 2006).

Since each point was sampled four times, in each sampling we recorded if each species of bird was detected or not. Thus, the detection history for each bird species in each area was obtained. The detection history was then used to estimate the probability of occupancy of the species.

For this model, the estimated parameters (occupancy and detectability) may be a function of covariates. The PRESENCE software (Hines 2006) recognizes two types of covariates, (1) site-specific covariates, which are constant for the site within the same season, e.g., habitat type, fragment size, or generalized weather patterns, such as drought or El Niño; and (2) sampling-occasion covariates, which may vary at each sampling, such as temperature, precipitation, time of day or observer (Hines 2006). In order to verify the probability of occupation of the bird species in each of the habitats, in the present study the first type of covariant was used. Thus, we tested whether the probability of occupancy of each species of bird occurred as a function of habitat. We ran occupancy models which assumed that the occupancy and detection of the species were constant - null models (e.g., same probability of occurrence among all points sampled), models that assumed that the probability of species occupancy was in function of the covariant habitat, models that assumed that species detection was a function of covariant habitat and models who assumed that the probability of species occupancy and species detection was in function of the covariant habitat.

We used the Akaike Information Criterion (AIC, Burnham \& Anderson 2002) for small sample sizes (AICc), to select the most parsimonious model. The best models were those with lower AICc values and higher AICc weights; the closer to 1 the AICc weight value, the greater the likelihood of the model being chosen as the best (Burnham \& Anderson 2002). This analysis was performed using PRESENCE 9.0 software (Hines 2006).

We used a contingency table to investigate the relationship between the number of birds associated 
with RE and IF habitats with their sensitivity to forest fragmentation (sensitive and non-sensitive). The bird species' level of sensitivity used was presented in Anjos (2006) and Anjos et al. (2011). Anjos (2006) determined the sensitivity of the birds to forest fragmentation in SF based on samplings carried out in 14 forest fragments of different sizes and degrees of isolation. Species were considered sensitive if they occurred only in control fragments or in large, non-isolated fragments; species not sensitive to forest fragmentation were those that occurred in all fragments, including the smallest and most isolated ones (Anjos 2006). In the present study we used two criteria to determine if a given species of bird was associated with one of the habitats, RE or FI: 1) the species should be exclusive to one habitat and with at least three contacts during the total sampling period; or 2) the species should have a higher probability of occupancy in one of the habitats. The software Past 3.0 was used to calculate the contingency table (Hammer et al. 2001).

The taxonomy and nomenclature followed American Ornithologists' Union - South American Classification Committee Checklist for South American Birds (SACC; Remsen-Jr. et al. 2016).

\section{RESULTS}

We recorded a total of 80 species of birds in both habitats, similar to the estimated richness $\left(\mathrm{Chao}_{1}, 84 \pm\right.$ 4 species). We detected no autocorrelation between the geographical distances of the sample units and the species composition (Mantel $r=0.063, P=0.320$ ). We recorded 65 bird species in RE and 68 in FI. The number of species estimated by Chao ${ }_{1}$ for $\mathrm{RE}$ was $70 \pm 4$ species and the estimated number for FI was $79 \pm 6$ species. Therefore, we found no difference between the estimated richness of the two habitats. Twelve species were recorded only in RE and 15 were exclusive to FI (Appendix II).

The composition of bird communities differed between habitats (PERMANOVA, Pseudo- $F=6.785, P$ $<0.010)$. In concordance with this result, the ordering of the NMDS showed that the RE and FI sample units differ in composition and abundance of bird species, as they were grouped separately (Fig. 2).

Among the 53 species that occurred both in RE and FI, the habitat type influenced the probability of occupancy of 20 species (Appendix III). Six species had a higher probability of occupancy in RE (Melanerpes flavifrons, Xiphocolaptes albicollis, Capsiempis flaveola, Platyrinchus mystaceus, Sirystes sibilator, Saltator similis) and 14 species showed a higher probability of occupation in FI (Crypturellus obsoletus, Trogon rufus, Pteroglossus castanotis, Hypoedaleus guttatus, Dysithamnus mentalis, Conopophaga lineata, Grallaria varia, Chamaeza campanisona, Dendrocolaptes platyrostris, Leptopogon amaurocephalus, Schiffornis virescens, Cyanocorax chrysops, Trichothraupis melanops, Basileuterus culicivorus).

Considering the set of species analyzed, 15 bird species were more associated to RE habitat, of which three are sensitive and 12 are not sensitive to forest fragmentation. Twenty-three bird species were more associated to FI habitat, of which 14 are sensitive and 9 are not sensitive to forest fragmentation (Appendix IV). Thus, the data suggest that species of birds susceptible to habitat fragmentation were those associated with the FI habitat while those that are not sensitive to fragmentation were those associated with $\mathrm{RE}$ habitat $\left(\chi^{2}=6.13 ; P=\right.$ $0.013)$.

\section{DISCUSSION}

We found a significant difference between the composition of the bird communities of RE and FI habitats, although the species richness was similar. The difference in the composition was due to several exclusive species in each habitat and to several species that occurred in both habitats but which showed greater occupancy in only one habitat. Species associated with the RE habitat tend not to be sensitive to forest fragmentation. In the study by Anjos (2006) on the sensitivity of birds to forest fragmentation, species that present tolerance to edges showed low sensitivity to fragmentation. The results of the present study indicate that of the total species associated to the RE habitat, only $20 \%$ are sensitive to forest fragmentation, while $61 \%$ of the species associated to the FI habitat are sensitive to forest fragmentation (Appendix IV).

A large number of physical and biological processes occur from the edge of a fragment because of the influence of the matrix habitat (Laurance et al. 2011). This influence on physical and biological processes occurs up to 200 $500 \mathrm{~m}$ from the border into the fragment (Laurance et al. 2011). Therefore, small and/or very elongated fragments are "all edge", that is, without an interior free of edge effects. These processes can affect forest bird species. Species associated with FI, such as Micrastur semitorquatus, Automolus leucophtalmus, Grallaria varia and Schiffornis virescens do not occur in fragments smaller than 60 ha; on the other hand, of the 15 species associated with RE, about $67 \%$ persist in small forest fragments of 11 and 25 ha (Anjos 2001). We should highlight that non-forest colonizer bird species occur in the edge of forest fragments. Those are species from open and/or Cerrado areas, such as Rupornis magnirostris, Colaptes melanochloros, Melanerpes candidus, Patagioenas maculosa and Myiarchus swainsoni (Anjos 2001, Baptista et al. 2016, Bierregaard et al. 2016, Joseph 2016, Winkler et al. 2016). Thus, the composition 
of birds of the edge of a forest fragment should originate mainly from those living on river banks in continuous forest combined with those colonizers from open areas. However, some species of interior forest can also persist in the fragments. Anjos (2001) studied the bird community in small forest fragments (56, 25 and 11 ha in size). Based on the present study and in Anjos et al. (2007), we found that the majority of the bird species that live in these small fragments are species that inhabit river bank and/or are colonizing species: $80 \%$ in FA, $82 \%$ in FB and $84 \%$ in FC.

Fragmentation and habitat degradation cause changes in the forest edge, such as increased temperature and light intensity. In Neotropical forests, birds that live on riverbanks in a continuous forest and occupy the edge of the remaining habitat after fragmentation and birds from open areas should select similar abiotic conditions such as air temperature, spatial variation of solar radiation, humidity and wind speed. On the other hand, forest species, such as understory insectivorous birds, select microhabitats with different abiotic characteristics and do not occupy the edge of the small forest fragments or fragments considered "all border" (Pollock et al. 2015, Stratford \& Stouffer 2015). In fact, birds associated with darker microhabitats are more sensitive to forest edge than birds that use brighter microhabitats (Patten \& Smith-Patten 2012). However, the forest interior is also home to several sensitive species to forest fragmentation, which are not particularly associated to forest understory, such as Pionopsitta pileata, one of the most threatened species of psittacines due to the massive destruction of their habitat (Sigrist 2013), which occurred exclusively in the FI habitat. It is important to point out that in RE there were also species that were exclusive of that habitat and are sensitive to forest fragmentation, such as Coccyzus melacoryphus, Hylopezus nattereri and Tityra cayana. The reason of these species' sensitivity may be related to the vegetation structure, or even the lower humidity of the edges of a fragment compared to the river's edge (Pollock et al. 2015).

When comparing the results of the present study with those obtained in the interior of São Paulo state by Cândido-Jr. (2000), who compared the avifauna between the edge of the fragment and the forest interior, similarities are found. Three species were most associated with the forest interior in both studies: A. leucophtalmus, D. platyrostris and T. melanops. However, one species, Tachyphonus coronatus, presented different results: in the present study it was associated to the RE habitat and in the cited study it was associated to the forest interior. This species inhabits the edge of the forest, capoeiras, parks, gardens and adapts well to a variety of edges, disturbed habitats and secondary forests (Sick 1997, Hilty 2016); more than $60 \%$ of the diet of this species is composed by invertebrates (Wilman et al. 2014). Populations at the edge of their geographical distribution are generally smaller than those closest to the center of the geographical distribution (Holt et al. 2005). The INP is situated on the southern edge of the geographical distribution of $T$. coronatus. It is possible that the population of $T$. coronatus in the INP is smaller than the population of the species at the site studied by Cândido-Jr. (2000). Perhaps in INP the individuals of this species were concentrated in the habitat RE due to greater availability of some type of resource or even by competition and the presence of predators.

In this study we demonstrated that river-edge bird species of a continuous area of forest form a significant part of the bird communities that persist in small forest fragments, with intense edge effect. This shows that not all the forest edge species are the result of colonization from open habitats. As expected, species that occupy the most remote areas of the river vegetation in a continuous forest are those most sensitive to forest fragmentation.

\section{ACKNOWLEDGEMENTS}

This study was funded in part by the Coordenação de Aperfeiçoamento de Pessoal de Nivel Superior - Brasil (CAPES) - B.R.A.L. received CAPES "sandwich doctorate" scholarship (99999.012747/2013-00) and G.M.B. received CAPES "sandwich doctorate" scholarships (99999.012746/2013-04). L.d.A. received financial support from CNPq (Brazilian Council for Development of Science and Technology, Brasilia; 306293/2014-5). Chico Mendes Institute for Conservation of Biodiversity (ICMBio, Brasilia) gave us permission (36241-2) to study birds in the Iguaçu National Park, where we had the assistance of PIC Ceu Azul staff. We thank J.M. Lindsey, a native speaker from the United States, for English proofreading. K. Sieving provided helpful comments and suggestions for this manuscript.

\section{REFERENCES}

Anderson M.J. 2001. A new method for non-parametric multivariate analysis of variance. Austral Ecology 26: 32-46.

Anjos L. 2001. Bird communities in five Atlantic Forest fragments in southern Brazil. Ornitología Neotropical 12: 11-27.

Anjos L. 2006. Bird species sensitivity in a fragmented landscape of the Atlantic Forest in southern Brazil. Biotropica 38: 229-234.

Anjos L. 2007. A eficiência do método de amostragem por pontos de escuta na avaliaçáo da riqueza de aves. Revista Brasileira de Ornitologia 15: 239-243.

Anjos L., Volpato G.H., Lopes E.V., Serafini P.P., Poletto F. \& Aleixo A. 2007. The importance of riparian forest for the maintenance of bird species richness in an Atlantic Forest remnant, southern Brazil. Revista Brasileira de Zoologia 24: 1078-1086. 
Anjos L., Volpato G.H., Mendonca L.B., Serafini P.P., Lopes E.V., Bocon R. \& Bisheimer M.V. 2010. Técnicas de levantamento quantitativo de aves em ambiente florestal: uma análise comparativa baseada em dados empíricos, p. 63-76. In: von Matter S., Straube F. Accordi I., Piacentini V.Q. \& Cândido-Jr. J.F. (eds.). Ornitologia e conservaçâo: ciência aplicada, técnicas de pesquisa e levantamento. Rio de Janeiro: Technical Books.

Anjos L., Collins C.D., Holt R.D., Volpato G.H., Mendonça L.B., Lopes E.V., Boçon R., Bisheimer M.V., Serafini P.P. \& Carvalho J. 2011. Bird species abundance-occupancy patterns and sensitivity to forest fragmentation: implications for conservation in the Brazilian Atlantic Forest. Biological Conservation 144: 2213-2222.

Anjos L., Volpato G.H., Lopes E.V., Willrich G., Bochio G.M., Arakaki Lindsey B.R., Simões N.R., Mendonça L.B., Boçon R, Carvalho J. \& Lima M.R. 2018. Distributions of birds and plants in ecoregions: implications for the conservation of a Neotropical biodiversity hotspot. Austral Ecology 43: 839-849.

Baptista L.F., Trail P.W., Horblit H.M., Kirwan G.M., Boesman P. \& Garcia E.F.J. 2016. Spot-winged Pigeon (Patagioenas maculosa). In: del Hoyo J., Elliott A., Sargatal J., Christie D.A. \& de Juana E. (eds.). Handbook of the birds of the world alive. Barcelona: Lynx Editions. http://www.hbw.com/node/54131 (Access on 02 December 2016).

Berduc A., Lorenzón R.E. \& Beltzer A.H. 2015. Patrones de diversidad de aves a lo largo de un gradiente latitudinal de bosques ribereños del Río Paranámedio, Argentina. Revista Mexicana de Biodiversidad 86: 419-430.

Bianchini E., Pimenta J.A. \& Santos F.A. 2001. Spatial and temporal variation in the canopy cover in a tropical semi-deciduous forest. Brazilian Archives of Biology and Technology 44: 269-276.

Bibby C., Burgess N.D. \& Hill D.A.1993. Bird census techniques. London: Academic Press.

Bierregaard R.O., Boesman P. \& Kirwan G.M. 2016. Roadside Hawk (Rupornis magnirostris). In: del Hoyo J., Elliott A., Sargatal J., Christie D.A. \& de Juana E. (eds.). Handbook of the birds of the world alive. Barcelona: Lynx Editions. http://www.hbw.com/ node/53121 (Access on 02 December 2016).

Burnham K.P. \& Anderson D.R. 2002. Model selection and multimodel inference: a practical information-theoretic approach, $2^{\text {nd }} e d n$. New York: Springer-Verlag.

Cândido-Jr. J.F. 2000. The edge effect in a forest bird community in Rio Claro, Sáo Paulo state, Brazil. Revista Brasileira de Ornitologia 8: 9-16.

Cavarzere V., Moraes G.P., Roper J.J., Silveira L.F. \& Donatelli R.J. 2013. Recommendations for monitoring avian populations with point counts: a case study in southeastern Brazil. Papéis Avulsos de Zoologia 53: 439-449.

Chan E.K.W., Yu Y.T, Zhang Y. \& Dudgeon D. 2008. Distribution patterns of birds and insect prey in a tropical riparian forest. Biotropica 40: 623-629.

Clarke K.R. 1993. Non-parametric multivariate analyses of changes in community structure. Austral Ecology 18: 117-143.

Clarke K.R. \& Gorley R.N. 2006. Primer v6: user manualltutorial. Plymouth: Plymouth Marine Laboratory.

Domínguez-López M.E. \& Ortega-Álvarez R. 2014. The importance of riparian habitats for avian communities in a highly human modified Neotropical landscape. Revista Mexicana de Biodiversidad 85: 1217-1227.

Gimenes M.R. \& Anjos L. 2003. Efeitos da fragmentação florestal sobre as comunidades de aves. Acta Scientiarum: Biological Sciences 25: 391-402.

Gomez D.M. \& Anthony R.G. 1998. Small mammal abundance in riparian and upland areas of five seral stages in western Oregon. Northwest Science 72: 293-302.

Gomez D., Rivera L., Politi N. \& Ruggera R. 2016. Avifauna de los bosques ribereńos de las selvas pedemontanas del noroeste argentino. Ornitología Neotropical 27: 47-57.

Guimarães A.E., Lopes C.M., Mello R.P. \& Alencar J. 2003. Mosquito (Diptera, Culicidae) ecology in the Iguaçu National Park, Brazil: habitat distribution. Caderno de Saúde Pública 19: 1107-1116.

Hammer Ø., Harper D.T.A. \& Ryan P.D. 2001. PAST: Palaeontological statistics. https://folk.uio.no/ohammer/past/ (Access on 01 October 2018).

Hansbauer M.M., Storch I., Leu S., Nieto-Holguin J.P., Pimentel R.G., Knauer F. \& Metzger J.P.W. 2008. Movements of Neotropical understory passerines affected by anthropogenic forest edges in the Brazilian Atlantic Rainforest. Biological Conservation 141: 782-791.

Herzog S.K., Kessler M. \& Cahill T.M. 2002. Estimating species richness of tropical bird communities from rapid assessment data. Auk 119: 749-769.

Hilty S. 2016. Ruby-crowned Tanager (Tachyphonus coronatus). In: del Hoyo J., Elliott A., Sargatal J., Christie D.A. \& de Juana E. (eds.). Handbook of the birds of the world alive. Barcelona: Lynx Editions. http://www.hbw.com/node/61617 (Access on 17 November 2016).

Hines J.E. 2006. PRESENCE 9. Software to estimate patch occupancy and related parameters. USGS-PWRC. https://www.mbr-pwrc. usgs.gov/software/presence.html (Access on 01 October 2018).

Holt R.D., Keitt T.H., Lewis M.A., Maurer B.A. \& Taper M.L. 2005. Theoretical models of species' borders: single species approaches. Oikos 108: 18-27.

ICMBio 1999. Plano de manejo do Parque Nacional do Iguaçu. http:// www.cataratasdoiguacu.com.br/manejo/siuc/planos_de_manejo/ pni/html/index.htm (Access on 21 April 2016).

ICMBio. 2014. Parque Nacional do Iguaçu. http://www.icmbio.gov. br/parnaiguacu (Access on 05 May 2016).

Joseph L. 2016. Swainson's Flycatcher (Myiarchus swainsoni). In: del Hoyo J., Elliot A., Sargatal J., Christie D.A. \& de Juana E. (eds.). Handbook of the birds of the world alive. Barcelona: Lynx Editions. http://www.hbw.com/node/57499 (Access on 02 December 2016).

Kajtoch L., Wilk T., Bobrek R. \& Matysek M. 2016. The importance of forests along submontane stream valleys for bird conservation: the Carpathian example. Bird Conservation International 26: 350365.

Kindt R. \& Coe R. 2005. Tree diversity analysis: a manual and software for common statistical methods for ecological and biodiversity studies. Nairobi: World Agroforestry Centre (ICRAF).

Laurance W.F., Camargo J.L.C., Luizão R.C.C., Laurance S.G., Pimm S.T.L., Bruna E.M., Stouffer P.C., Williamson G.B., BenítezMalvido J., Vasconcelos H.L., Houtan K.S.V., Zartman C.E., Boyle S.A., Didham R.K., Andrade A. \& Lovejoy T.E. 2011. The fate of Amazonian Forest fragments: a 32-year investigation. Biological Conservation 144: 56-67.

Legendre P. \& Legendre L. 1998. Numerical ecology. Amsterdan: Elsevier Science.

MacKenzie D.I., Nichols J.D., Lachman G.B., Droege S., Royle J.A. \& Langtimm C.A. 2002. Estimating site occupancy rates when detection probabilities are less than one. Ecology 83: 2248-2255.

MacKenzie D.I., Nichols J.D., Royle J.A., Pollock K.H., Bailey L.L. \& Hines J.E. 2006. Occupancy estimation and modeling: inferring patterns and dynamics of species occurrence. Burlington: Elsevier.

McGarigal K. \& McComb W.C. 1992. Streamside versus upslope breeding bird communities in the central Oregon coast range. Journal of Wildlife Management 56: 10-23.

Melo L.A.M.N., Soares R.V., Siqueira J.D.P. \& Kirchner F.F. 2006. Modelagem de combustíveis florestais no Parque Nacional do Iguaçu, PR, Brasil. Floresta 36: 415-424.

Mittermeier R.A., Turner W.R., Larsen F.W., Brooks T.M. \& Gascon C. 2011. Global biodiversity conservation: the critical role of hotspots. In: F.E. Zachos \& Habel J.C. (eds.). Biodiversity 
hotspots: distribution and protection of conservation priority areas. Heidelberg: Springer.

Morellato L.P.C \& Haddad C.F.B. 2000. Introduction: the Brazilian Atlantic Forest. Biotropica 32: 786-792.

Morin P.J. 2011. Community ecology. Oxford: Wiley-Blackwell.

Naiman R.J., de Décamps H. \& Pollock M. 1993. The role of riparian corridors in maintaining regional biodiversity. Ecological Applications 3: 209-212.

Oliveira-Filho A.T. \& Fontes M.A.L. 2000. Patterns of floristic differentiation among Atlantic Forests in southeastern Brazil and the influence of climate. Biotropica 32: 793-810.

Oksanen J., Blanchet F.G., Friendly M., Kindt R., Legendre P., McGlinn D., Minchin P.R., O'Hara R.B., Simpson G.L., Solymos P., Stevens M.H.H., Szoecs E. \& Wagner H. 2016. Vegan: community ecology package. http://CRAN.Rproject.org/ package $=$ vegan

Patten M.A. \& Smith-Patten B.D. 2012. Testing the microclimate hypothesis: light environment and population trends of Neotropical birds. Biological Conservation 155: 85-93.

Peres C.A. 1997. Primate community structure at twenty Amazonian flooded and unflooded forests. Journal of Tropical Ecology 13: 381-405.

Pollock H.S., Cheviron Z.A., Agin T.J. \& Brawn J.D. 2015. Absence of microclimate selectivity in insectivorous birds of the Neotropical forest understory. Biological Conservation 188: 116-125.

R Development Core Team. 2015. R: a language and environment for statistical computing. Vienna: R Foundation for Statistical Computing. https://www.R-project.org/.

Rannestad O.T., Tsegaye D., Muniah P.K.T. \& Moe S.R. 2015. Bird abundance, diversity and habitat preferences in the riparian zone of a disturbed wetland ecosystem: the Kilombero Valley, Tanzania. Wetlands 35: 521-532.

Remsen-Jr. J.V., Areta J.I., Cadena C.D., Claramunt S., Jaramillo A., Pacheco J.F., Perez-Eman J., Robbins M.B., Stiles F.G., Stotz D.F. \& Zimmer K.Z. 2016. A classification of the bird species of South America. Chicago: American Ornithologists' Union.

Rykken J.J., Moldenke A.R. \& Olson D.H. 2007. Headwater riparian forest-floor invertebrate communities associated with alternative management practices. Ecological Applications 17: 1168-1183.

Scheer M.B. \& Blum C.T. 2011. Arboreal diversity of the Atlantic Forest of southern Brazil: from the beach ridges to the Paraná River, p. 110-134. In: Grillo O. \& Venora G. (eds.). The dynamical processes of biodiversity-case studies of evolution and spatial distribution. Rijeka: Intech.
Shirley S.M. 2005. Habitat use by riparian birds in old-growth coastal British Columbia rainforest. Willson Bulletin 117: 245-257.

Sekercioglu Ç.H., Loarie S.R., Oviedo-Brenes F., Mendehall C.D., Daily G.C. \& Ehrlich P.R. 2015. Tropical countryside riparian corridors provide critical habitat and connectivity for seeddispersing forest birds in a fragmented landscape. Journal of Ornithology 156: S343-S353.

Sick H. 1997. Ornitologia brasileira. Rio de Janeiro: Nova Fronteira.

Sigrist T. 2013. Avifauna brasileira. Vinhedo: Avisbrasilis.

Stratford J.A. \& Stouffer P.C. 2015. Forest fragmentation alters microhabitat availability for Neotropical terrestrial insectivorous birds. Biological Conservation 188: 109-115.

Tabarelli M, Aguiar A.V., Ribeiro M.C., Metzger J.P. \& Peres C.A. 2010. Prospects for biodiversity conservation in the Atlantic Forest: lessons from aging human-modified landscapes. Biological Conservation 143: 2328-2340.

Veloso H.P., Range-Filho A.L.R. \& Lima J.C.A. 1991. Classificação da vegetaçâo Brasileira, adaptada a um sistema universal. Rio de Janeiro: IBGE.

Vielliard J.M.E. \& Silva W.R. 1990. Nova metodologia de levantamento quantitativo e primeiros resultados no interior do estado de São Paulo, Brasil, p. 117-151. In: Anais do IV Encontro Nacional dos Anilhadores de Aves. Recife: Cemave.

Willrich G., Calsavara L.C., Lima M.R., Oliveira R.C., Bochio G.M., Rosa G.L.M., Muzi V.C. \& Anjos L. 2016. Twenty-three years of bird monitoring reveal low extinction and colonization of species in a reserve surrounded by an extremely fragmented landscape in southern Brazil. Revista Brasileira de Ornitologia 24: 235-259.

Wilman H., Belmaker J., Simpson J., Rosa C., Rivadeneira M.M. \& Jetz W. 2014. EltonTraits 1.0: species-level foraging attributes of the world's birds and mammals. Ecology 95: 2027.

Winkler H., Christie D.A. \& Kirwan G.M. 2016. Green-barred Woodpecker (Colaptes melanochloros). In: del Hoyo J., Elliot A., Sargatal J., Christie D.A. \& de Juana E. (eds.). Handbook of the birds of the world alive. Barcelona: Lynx Editions. http://www. hbw.com/node/56267 (Access on 23 November 2016).

Woinarski J.C.Z., Brock C., Armstrong C., Hempel C., Cheal D. \& Brennan K. 2000. Bird distribution in riparian vegetation in the extensive natural landscape of Australia's tropical savanna: a broad scale survey and analysis of a distributional database. Journal of Biogeography 27: 843-868.

Associate Editor: Marcos P. Dantas.

\section{APPENDIX I}
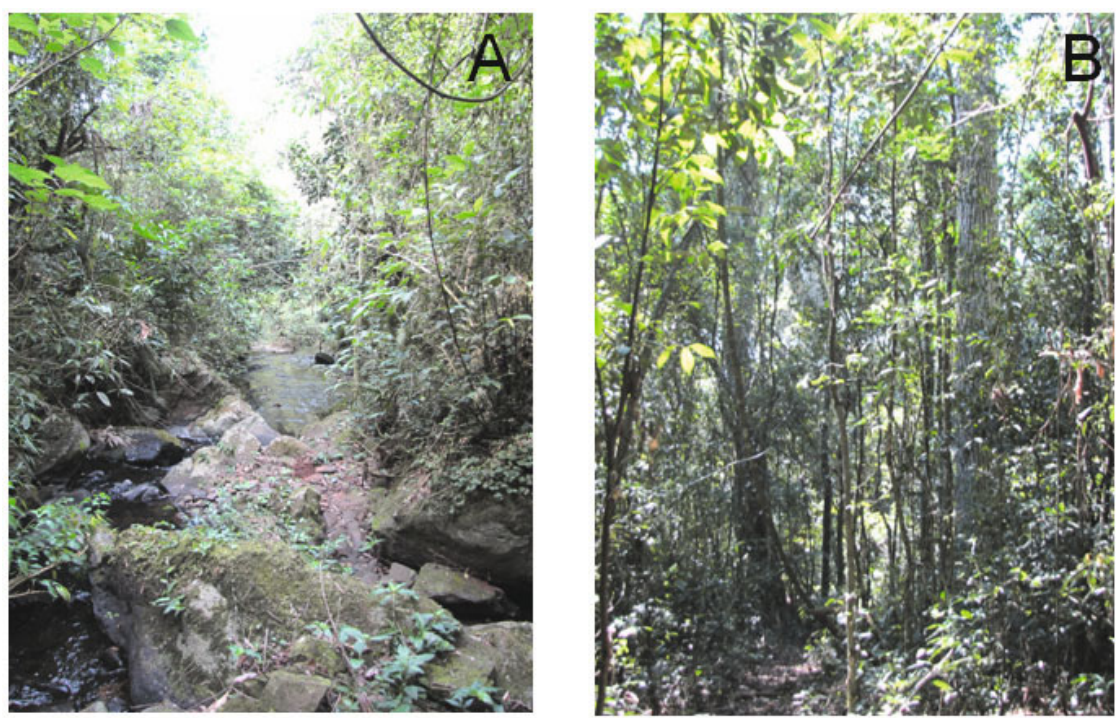

Figure 1. Sites sampled in the INP: A) "River Edge", on the edge of a tributary of the Azul River, and B) "Forest Interior". 


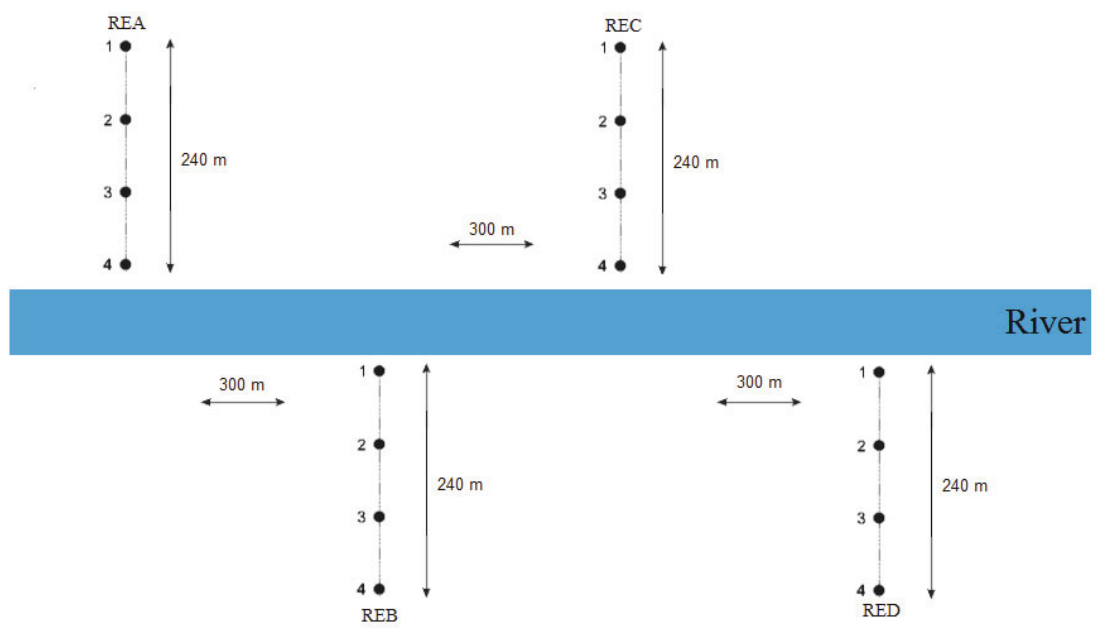

Figure 2. The four points of each of the trails (REA, REB, REC and RED) in the River Edge habitat sampled at INP.

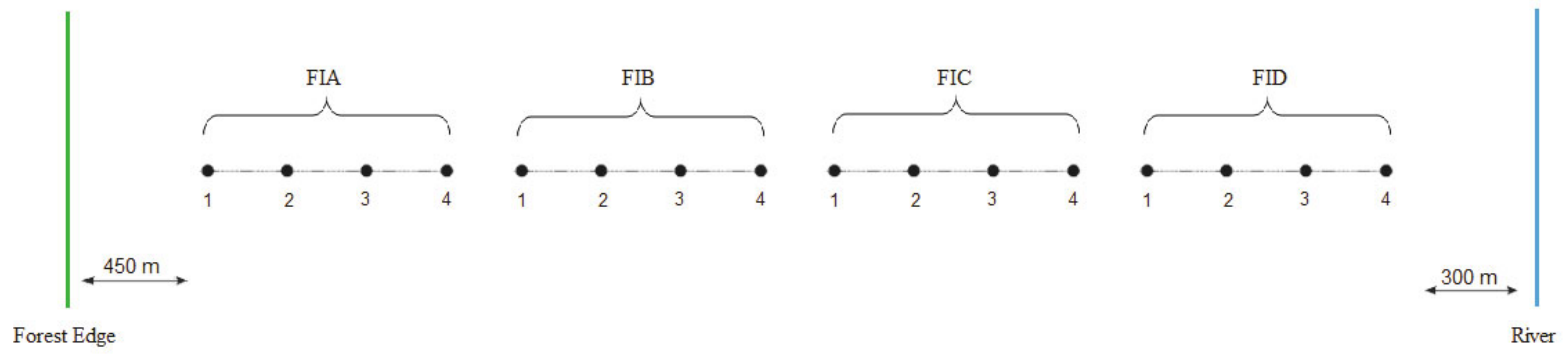

Figure 3. The four blocks (FIA, FIB, FIC and FID) of four points located on the trail of FI habitat at INP.

\section{APPENDIX II}

Families and bird species sampled in RE and FI habitats at INP. Taxonomy follows American Ornithologists' Union South American Classification Committee Checklist for South American Birds (Remsen-Jr. et al. 2016).

\begin{tabular}{lll}
\hline \multirow{2}{*}{ Bird species } & & Presence \\
\cline { 2 - 3 } & RE & FI \\
\hline TINAMIDAE & & \\
Crypturellus obsoletus & $\mathrm{X}$ & $\mathrm{X}$ \\
Crypturellus parvirostris & & $\mathrm{X}$ \\
Crypturellus tataupa & $\mathrm{X}$ & $\mathrm{X}$ \\
COLUMBIDAE & & \\
Patagioenas picazuro & $\mathrm{X}$ & $\mathrm{X}$ \\
Geotrygon montana & $\mathrm{X}$ & \\
Leptotila verreauxi & $\mathrm{X}$ & \\
CUCULIDAE & & $\mathrm{X}$ \\
Piaya cayana & $\mathrm{X}$ & $\mathrm{X}$ \\
Coccyzus melacoryphus & $\mathrm{X}$ & $\mathrm{X}$ \\
TROCHILIDAE & & \\
Phaethornis pretrei & & \\
\hline
\end{tabular}




\begin{tabular}{lll}
\multicolumn{3}{c}{ Presence } \\
\hline RE & FI \\
\hline
\end{tabular}

\section{TROGONIDAE}

Trogon surrucura

X

$\mathrm{X}$

Trogon rufus

$\mathrm{X}$

$\mathrm{X}$

MOMOTIDAE

Baryphthengus ruficapillus

X

X

RAMPHASTIDAE

Ramphastos dicolorus

Selenidera maculirostris

X

$\mathrm{X}$

Pteroglossus castanotis

X

$\mathrm{X}$

$\mathrm{X}$

PICIDAE

Picumnus temminckii

X

Melanerpes flavifrons

X

$\mathrm{X}$

Colaptes melanochloros

X

Dryocopus lineatus

X

Campephilus robustus

X

X

X

FALCONIDAE

Micrastur semitorquatus

Milvago chimachima

$\mathrm{X}$

$\mathrm{X}$

PSITTACIDAE

Pionopsitta pileata

Pionus maximiliani

$\mathrm{X}$

Pyrrhura frontalis

Psittacara leucophthalmus

$\mathrm{X}$

$\mathrm{X}$

X

$\mathrm{X}$

$\mathrm{X}$

THAMNOPHILIDAE

Hypoedaleus guttatus

$\mathrm{X}$

Mackenziaena severa

X

Thamnophilus caerulescens

$\mathrm{X}$

Dysithamnus mentalis

$\mathrm{X}$

Herpsilochmus rufimarginatus

$\mathrm{X}$

Drymophila rubricollis

Drymophila malura

Pyriglena leucoptera

$\mathrm{X}$

$\mathrm{X}$

$\mathrm{X}$

CONOPOPHAGIDAE

Conopophaga lineata

X

X

$\mathrm{X}$

$\mathrm{X}$

GRALLARIIDAE

Grallaria varia

X

Hylopezus nattereri

$\mathrm{X}$

RHINOCRYPTIDAE

Eleoscytalopus indigoticus

X

X

FORMICARIIDAE

Chamaeza campanisona

$\mathrm{X}$

$\mathrm{X}$

Chamaeza meruloides

$\mathrm{X}$

X 


\begin{tabular}{|c|c|c|}
\hline \multirow{2}{*}{ Bird species } & \multicolumn{2}{|c|}{ Presence } \\
\hline & $\mathbf{R E}$ & FI \\
\hline \multicolumn{3}{|l|}{ FURNARIIDAE } \\
\hline Sittasomus griseicapillus & $\mathrm{X}$ & $\mathrm{X}$ \\
\hline Dendrocincla fuliginosa & $\mathrm{X}$ & $\mathrm{X}$ \\
\hline Dendrocolaptes platyrostris & $\mathrm{X}$ & $\mathrm{X}$ \\
\hline Xiphocolaptes albicollis & $\mathrm{X}$ & $\mathrm{X}$ \\
\hline Xiphorhynchus fuscus & & $\mathrm{X}$ \\
\hline Lochmias nematura & $\mathrm{X}$ & \\
\hline Anabacerthia lichtensteini & $\mathrm{X}$ & $\mathrm{X}$ \\
\hline Automolus leucophthalmus & & $\mathrm{X}$ \\
\hline Synallaxis ruficapilla & $\mathrm{X}$ & $\mathrm{X}$ \\
\hline \multicolumn{3}{|l|}{ TYRANNIDAE } \\
\hline Myiopagis caniceps & $\mathrm{X}$ & $\mathrm{X}$ \\
\hline Camptostoma obsoletum & $\mathrm{X}$ & $\mathrm{X}$ \\
\hline Capsiempis flaveola & $\mathrm{X}$ & $\mathrm{X}$ \\
\hline Leptopogon amaurocephalus & $\mathrm{X}$ & $\mathrm{X}$ \\
\hline Hemitriccus diops & $\mathrm{X}$ & \\
\hline Poecilotriccus plumbeiceps & $\mathrm{X}$ & $\mathrm{X}$ \\
\hline Tolmomyias sulphurescens & $\mathrm{X}$ & \\
\hline Platyrinchus mystaceus & $\mathrm{X}$ & $\mathrm{X}$ \\
\hline Lathrotriccus euleri & $\mathrm{X}$ & $\mathrm{X}$ \\
\hline Pitangus sulphuratus & & $\mathrm{X}$ \\
\hline Myiodynastes maculatus & $\mathrm{X}$ & \\
\hline Megarynchus pitangua & $\mathrm{X}$ & $\mathrm{X}$ \\
\hline Sirystes sibilator & $\mathrm{X}$ & $\mathrm{X}$ \\
\hline \multicolumn{3}{|l|}{ TITYRIDAE } \\
\hline Tityra cayana & $\mathrm{X}$ & \\
\hline Schiffornis virescens & $\mathrm{X}$ & $\mathrm{X}$ \\
\hline \multicolumn{3}{|l|}{ INCERTAE SEDIS } \\
\hline Piprites chloris & & $\mathrm{X}$ \\
\hline \multicolumn{3}{|l|}{ CORVIDAE } \\
\hline Cyanocorax chrysops & $\mathrm{X}$ & $\mathrm{X}$ \\
\hline \multicolumn{3}{|l|}{ TURDIDAE } \\
\hline Turdus leucomelas & $\mathrm{X}$ & $\mathrm{X}$ \\
\hline \multicolumn{3}{|l|}{ THRAUPIDAE } \\
\hline Cissopis leverianus & & $\mathrm{X}$ \\
\hline Trichothraupis melanops & $\mathrm{X}$ & $\mathrm{X}$ \\
\hline Tachyphonus coronatus & $\mathrm{X}$ & \\
\hline Dacnis cayana & & $\mathrm{X}$ \\
\hline Hemithraupis guira & $\mathrm{X}$ & \\
\hline Conirostrum speciosum & $\mathrm{X}$ & $\mathrm{X}$ \\
\hline \multicolumn{3}{|l|}{ INCERTAE SEDIS } \\
\hline Saltator similis & $\mathrm{X}$ & $\mathrm{X}$ \\
\hline
\end{tabular}




\begin{tabular}{|c|c|c|}
\hline \multirow{2}{*}{ Bird species } & \multicolumn{2}{|c|}{ Presence } \\
\hline & $\mathbf{R E}$ & FI \\
\hline \multicolumn{3}{|l|}{ CARDINALIDAE } \\
\hline Habia rubica & & $\mathrm{X}$ \\
\hline \multicolumn{3}{|l|}{ PARULIDAE } \\
\hline Setophaga pitiayumi & $\mathrm{X}$ & $\mathrm{X}$ \\
\hline Myiothlypis leucoblephara & $\mathrm{X}$ & $\mathrm{X}$ \\
\hline Basileuterus culicivorus & $\mathrm{X}$ & $\mathrm{X}$ \\
\hline \multicolumn{3}{|l|}{ ICTERIDAE } \\
\hline Cacicus haemorrhous & $\mathrm{X}$ & $\mathrm{X}$ \\
\hline Cacicus haemorrhous & $\mathrm{X}$ & $\mathrm{X}$ \\
\hline \multicolumn{3}{|l|}{ FRINGILLIDAE } \\
\hline Euphonia pectoralis & & $\mathrm{X}$ \\
\hline
\end{tabular}

\section{APPENDIX III}

Best models tested for occupancy probability as a function of the different habitat types (RE and FI) at INP, for the bird species that occurred in both habitats. Occupancy $(\Psi)$; Probability of detection (p); Difference between the AICc models $(\triangle \mathrm{AICc})$. Taxonomy follows American Ornithologists' Union - South American Classification Committee Checklist for South American Birds (Remsen-Jr. et al. 2016).

\begin{tabular}{|c|c|c|c|}
\hline Bird species & Model & $\Delta \mathrm{AICc}$ & AICc Weight \\
\hline \multicolumn{4}{|l|}{ TINAMIDAE } \\
\hline Crypturellus obsoletus & $\Psi($ habitat $), \mathrm{p}()$. & 0.00 & 0.40 \\
\hline Crypturellus tataupa & $\Psi(),. \mathrm{p}($ habitat $)$ & 0.00 & 0.357 \\
\hline \multicolumn{4}{|l|}{ COLUMBIDAE } \\
\hline Patagioenas picazuro & $\Psi(),. \mathrm{p}()$. & 0.00 & 0.386 \\
\hline \multicolumn{4}{|l|}{ CUCULIDAE } \\
\hline Piaya cayana & $\Psi(),. \mathrm{p}()$. & 0.00 & 0.362 \\
\hline \multicolumn{4}{|l|}{ TROGONIDAE } \\
\hline Trogon surrucura & $\Psi(),. \mathrm{p}($ habitat $)$ & 0.00 & 0.317 \\
\hline Trogon rufus & $\Psi($ habitat $), \mathrm{p}()$. & 0.00 & 0.448 \\
\hline \multicolumn{4}{|l|}{ MOMOTIDAE } \\
\hline Baryphthengus ruficapillus & $\Psi(),. \mathrm{p}$ (habitat) & 0.00 & 0.404 \\
\hline \multicolumn{4}{|l|}{ RAMPHASTIDAE } \\
\hline Ramphastos dicolorus & $\Psi(),. \mathrm{p}()$. & 0.00 & 0.459 \\
\hline Selenidera maculirostris & $\Psi(),. \mathrm{p}()$. & 0.00 & 0.389 \\
\hline Pteroglossus castanotis & $\Psi($ habitat),p(.) & 0.00 & 0.523 \\
\hline \multicolumn{4}{|l|}{ PICIDAE } \\
\hline Melanerpes flavifrons & $\Psi($ habitat), $\mathrm{p}()$. & 0.00 & 0.369 \\
\hline Dryocopus lineatus & $\Psi(),. \mathrm{p}()$. & 0.00 & 0.402 \\
\hline \multirow[t]{3}{*}{ Campephilus robustus } & $\Psi(),. \mathrm{p}()$. & 0.00 & 0.358 \\
\hline & $\Psi(),. \mathrm{p}($ habitat $)$ & 1.34 & 0.183 \\
\hline & $\Psi($ habitat $), \mathrm{p}$ (habitat) & 2.57 & 0.099 \\
\hline
\end{tabular}




\begin{tabular}{|c|c|c|c|}
\hline Bird species & Model & $\Delta \mathrm{AICc}$ & AICc Weight \\
\hline \multicolumn{4}{|l|}{ PSITTACIDAE } \\
\hline \multirow[t]{3}{*}{ Pionus maximiliani } & $\Psi(),. \mathrm{p}()$. & 0.00 & 0.518 \\
\hline & $\Psi(),. \mathrm{p}$ (habitat) & 2.48 & 0.187 \\
\hline & $\Psi($ habitat $), \mathrm{p}$ (habitat) & 4.59 & 0.034 \\
\hline Pyrrhura frontalis & $\Psi(),. \mathrm{p}()$. & 0.00 & 0.323 \\
\hline Psittacara leucophthalmus & $\Psi(),. \mathrm{p}()$. & 0.00 & 0.298 \\
\hline \multicolumn{4}{|l|}{ THAMNOPHILIDAE } \\
\hline Hypoedaleus guttatus & $\Psi($ habitat $), \mathrm{p}()$. & 0.00 & 0.486 \\
\hline Mackenziaena severa & $\Psi(),. \mathrm{p}()$. & 0.00 & 0.417 \\
\hline Thamnophilus caerulescens & $\Psi(),. \mathrm{p}()$. & 0.00 & 0.358 \\
\hline Dysithamnus mentalis & $\Psi$ (habitat),p(.) & 0.00 & 0.617 \\
\hline Herpsilochmus rufimarginatus & $\Psi(),. \mathrm{p}()$. & 0.00 & 0.502 \\
\hline Drymophila malura & $\Psi(),. \mathrm{p}()$. & 0.00 & 0.293 \\
\hline Pyriglena leucoptera & $\Psi(),. \mathrm{p}()$. & 0.00 & 0.284 \\
\hline \multicolumn{4}{|l|}{ CONOPOPHAGIDAE } \\
\hline Conopophaga lineata & $\Psi($ habitat), $\mathrm{p}()$. & 0.00 & 0.482 \\
\hline \multicolumn{4}{|l|}{ GRALLARIIDAE } \\
\hline Grallaria varia & $\Psi($ habitat $), \mathrm{p}()$. & 0.00 & 0.439 \\
\hline \multicolumn{4}{|l|}{ RHINOCRYPTIDAE } \\
\hline Eleoscytalopus indigoticus & $\Psi(),. \mathrm{p}$ (habitat) & 0.00 & 0.270 \\
\hline \multicolumn{4}{|l|}{ FORMICARIIDAE } \\
\hline Chamaeza campanisona & $\Psi($ habitat $), \mathrm{p}()$. & 0.00 & 0.593 \\
\hline Chamaeza meruloides & $\Psi(),. \mathrm{p}()$. & 0.00 & 0.3586 \\
\hline \multicolumn{4}{|l|}{ FURNARIIDAE } \\
\hline Sittasomus griseicapillus & $\Psi(),. \mathrm{p}$ (habitat) & 0.00 & 0.486 \\
\hline Dendrocincla fuliginosa & $\Psi(),. \mathrm{p}()$. & 0.00 & 0.376 \\
\hline Dendrocolaptes platyrostris & $\Psi($ habitat $), \mathrm{p}()$. & 0.00 & 0.461 \\
\hline Xiphocolaptes albicollis & $\Psi($ habitat $), \mathrm{p}()$. & 0.00 & 0.360 \\
\hline Anabacerthia lichtensteini & $\Psi(),. \mathrm{p}()$. & 0.00 & 0.441 \\
\hline Synallaxis ruficapilla & $\Psi(),. \mathrm{p}()$. & 0.00 & 0.485 \\
\hline \multicolumn{4}{|l|}{ TYRANNIDAE } \\
\hline Myiopagis caniceps & $\Psi(),. \mathrm{p}()$. & 0.00 & 0.450 \\
\hline Camptostoma obsoletum & $\Psi(),. \mathrm{p}()$. & 0.00 & 0.407 \\
\hline Capsiempis flaveola & $\Psi($ habitat $), \mathrm{p}()$. & 0.00 & 0.468 \\
\hline Leptopogon amaurocephalus & $\Psi($ habitat), $\mathrm{p}()$. & 0.00 & 0.468 \\
\hline Poecilotriccus plumbeiceps & $\Psi(),. \mathrm{p}$ (habitat) & 0.00 & 0.348 \\
\hline Platyrinchus mystaceus & $\Psi($ habitat $), \mathrm{p}()$. & 0.00 & 0.389 \\
\hline Lathrotriccus euleri & $\Psi(),. \mathrm{p}($ habitat $)$ & 0.00 & 0.474 \\
\hline Megarynchus pitangua & $\Psi(),. \mathrm{p}$ (habitat) & 0.00 & 0.347 \\
\hline Sirystes sibilator & $\Psi($ habitat), $\mathrm{p}()$. & 0.00 & 0.506 \\
\hline \multicolumn{4}{|l|}{ TITYRIDAE } \\
\hline Schiffornis virescens & $\Psi($ habitat $), \mathrm{p}()$. & 0.00 & 0.640 \\
\hline
\end{tabular}




\begin{tabular}{|c|c|c|c|}
\hline Bird species & Model & $\Delta \mathrm{AICc}$ & AICc Weight \\
\hline \multicolumn{4}{|l|}{ CORVIDAE } \\
\hline Cyanocorax chrysops & $\Psi($ habitat),p(.) & 0.00 & 0.556 \\
\hline \multicolumn{4}{|l|}{ TURDIDAE } \\
\hline Turdus leucomelas & $\Psi(),. \mathrm{p}($ habitat $)$ & 0.00 & 0.468 \\
\hline \multicolumn{4}{|l|}{ THRAUPIDAE } \\
\hline Trichothraupis melanops & $\Psi($ habitat $), \mathrm{p}()$. & 0.00 & 0.349 \\
\hline Conirostrum speciosum & $\Psi(),. \mathrm{p}()$. & 0.00 & 0.358 \\
\hline \multicolumn{4}{|l|}{ INCERTAE SEDIS } \\
\hline Saltator similis & $\Psi($ habitat), $\mathrm{p}()$. & 0.00 & 0.317 \\
\hline \multicolumn{4}{|l|}{ PARULIDAE } \\
\hline Setophaga pitiayumi & $\Psi(),. \mathrm{p}()$. & 0.00 & 0.412 \\
\hline Myiothlypis leucoblephara & $\Psi(),. \mathrm{p}($ habitat $)$ & 0.00 & 0.338 \\
\hline Basileuterus culicivorus & $\Psi($ habitat $), \mathrm{p}()$. & 0.00 & 0.480 \\
\hline \multicolumn{4}{|l|}{ ICTERIDAE } \\
\hline Cacicus haemorrhous & $\Psi($ habitat $), \mathrm{p}$ (habitat) & 0.00 & 0.480 \\
\hline
\end{tabular}

\section{APPENDIX IV}

Bird species associated to river edge (RE) and forest interior (FI) habitats in the present study with their respective sensitivity to forest fragmentation (sensitive and non-sensitive) according to Anjos (2006) and Anjos et al. (2011).

\begin{tabular}{lcc}
\hline Bird species & Sensitive & Non-sensitive \\
\hline FI & & \\
Crypturellus obsoletus & $\mathrm{X}$ & $\mathrm{X}$ \\
Trogon rufus & $\mathrm{X}$ & \\
Pteroglossus castanotis & & $\mathrm{X}$ \\
Hypoedaleus guttatus & & $\mathrm{X}$ \\
Dysithamnus mentalis & & $\mathrm{X}$ \\
Conopophaga lineata & $\mathrm{X}$ & \\
Grallaria varia & $\mathrm{X}$ & \\
Chamaeza campanisona & & $\mathrm{X}$ \\
Dendrocolaptes platyrostris & & $\mathrm{X}$ \\
Leptopogon amaurocephalus & $\mathrm{X}$ & \\
Schiffornis virescens & $\mathrm{X}$ & \\
Cyanocorax chrysops & $\mathrm{X}$ & \\
Trichothraupis melanops & & $\mathrm{X}$ \\
Basileuterus culicivorus & $\mathrm{X}$ & \\
Phaethornis pretrei & $\mathrm{X}$ & $\mathrm{X}$ \\
Xiphorhynchus fuscus & & \\
Automolus leucophthalmus & $\mathrm{X}$ & \\
Piprites chloris & $\mathrm{X}$ & $\mathrm{X}$ \\
Dacnis cayana & $\mathrm{X}$ & \\
Pionopsitta pileata & & \\
Micrastur semitorquatus & & \\
\hline
\end{tabular}




\begin{tabular}{lcc}
\hline Bird species & Sensitive & Non-sensitive \\
\hline Euphonia pectoralis & $\mathrm{X}$ & \\
Picumnus temmincki & & $\mathrm{X}$ \\
$\mathbf{R E}$ & $\mathrm{X}$ & \\
Melanerpes flavifrons & & $\mathrm{X}$ \\
Xiphocolaptes albicollis & & $\mathrm{X}$ \\
Capsiempis flaveola & & $\mathrm{X}$ \\
Platyrinchus mystaceus & $\mathrm{X}$ & \\
Sirystes sibilator & & $\mathrm{X}$ \\
Saltator similis & & $\mathrm{X}$ \\
Geotrygon montana & & $\mathrm{X}$ \\
Colaptes melanochloros & & $\mathrm{X}$ \\
Hylopezus nattereri & & $\mathrm{X}$ \\
Lochmias nematura & & $\mathrm{X}$ \\
Hemitriccus diops & & $\mathrm{X}$ \\
Tolmomyias sulphurescens & $\mathrm{X}$ & $\mathrm{X}$ \\
Tityra cayana & & $\mathrm{X}$ \\
Tachyphonus coronatus & & \\
Hemithraupis guira & & \\
\hline
\end{tabular}

